\title{
First report of Botryosphaeria dothidea causing stem canker of hazelnut in Turkey
}

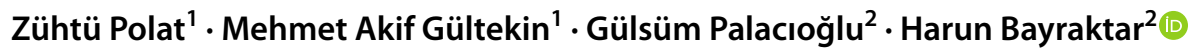

Received: 20 August 2021 / Accepted: 26 October 2021 / Published online: 3 November 2021

(c) Società Italiana di Patologia Vegetale (S.I.Pa.V.) 2021

Keywords Botryosphaeria dothidea $\cdot$ Corylus avellana $\cdot$ Wood necrosis $\cdot$ Canker

Hazelnut (Corylus avellana) is one of the most economically important tree nut crops in Turkey. In June 2021, canker and wood necrosis were observed on approximately $25 \%$ of hazelnut trees within an area of 4 hectares located in Sakarya province of Turkey. Disease symptoms were dark brown dried-up branches, brown necrosis of the internal tissues, and death of the trees. Infected wood tissues of six hazelnut trees were surface-disinfected in $2 \%$ sodium hypochlorite for $2 \mathrm{~min}$, rinsed in sterile distilled water and plated on potato dextrose agar. Petri dishes were kept at $23 \pm 1{ }^{\circ} \mathrm{C}$ for 10 days in dark. Fungal colonies from all samples were initially white with aerial mycelium, gradually turning dark grey and produced black pycnidia after about 20 days. Conidia were aseptate, hyaline, thin walled, smooth, elliptical to fusiform with a subobtuse apex and measured 20.4 to $27.3 \times 3.9$ to $5.8 \mu \mathrm{m}(\mathrm{n}=30)$. On the basis of these morphological characteristics, the fungus was identified as Botryosphaeria dothidea (Phillips et al. 2013). Morphological identification of the representative pathogen FB-1 was also confirmed by sequencing of the ribosomal internal transcribed spacer region (ITS) with primers ITS 1/ ITS4, the translation elongation factor 1-alpha (EF1- $\alpha)$ with EF1-728F/986R, and $\beta$-tubulin with Bt2a/Bt2b (Alves et al. 2006; White et al. 1990). The resulting sequences were submitted to GenBank database with accession Nos. MZ820655 for ITS, MZ821071 for EF1- $\alpha$ and OK484567 for $\beta$-tubulin. The sequences showed $100 \%$ identity with B. dothidea strain CBS 110302 (ITS: AY259092, EF1- $\alpha$ : AY573218, $\beta$-tubulin: EU673106). Phylogenetic analyses

Harun Bayraktar

bayrakta@agri.ankara.edu.tr

1 Atatürk Central Horticultural Research Institute, 77102 Yalova, Turkey

2 Department of Plant Protection, Faculty of Agriculture, Ankara University, 06110 Ankara, Turkey of three sequences clearly separated $B$. dothidea from other species. Koch's postulates were completed by inoculating six $30 \mathrm{~cm}$ long branch segments from two-year-old hazelnut trees. The bark tissue was removed with a cork borer and a mycelial plug was inserted. Six branch segments inoculated with PDA plugs served as controls. Wounds were wrapped with Parafilm and incubated at $25{ }^{\circ} \mathrm{C}$ and $80 \%$ humidity. After 3 weeks, all the inoculated branches showed dark tissue necrosis. B. dothidea was consistently reisolated from inoculated branches. Control branches did not show any symptoms. To our knowledge, this is the first report of $B$. dothidea associated with stem canker on hazelnut in Turkey.

\section{Declarations}

Ethical statement This article does not contain any studies with human participants or animals.

Conflict of interest All authors declare that they have no conflict of interests.

\section{References}

Alves A, Correia A, Phillips AJ (2006) Multi-gene genealogies and morphological data support Diplodia cupressi sp. nov., previously recognized as D. pinea f. sp. cupressi, as a distinct species. Fungal Divers 23:1-5

Phillips AJL, Alves A, Abdollahzadeh J, Slippers B, Wingfield MJ, Groenewald JZ, Crous PW (2013) The Botryosphaeriaceae: genera and species known from culture. Stud Mycol 76:51-167

White TJ, Bruns T, Lee SJ, Taylor JW (1990) Amplification and direct sequencing of fungal ribosomal RNA genes for phylogenetics. In Innis MA, Gelfand DH, Sninsky JJ, White TJ, editors. PCR protocols: a guide to methods and applications 18:315-22

Publisher's Note Springer Nature remains neutral with regard to jurisdictional claims in published maps and institutional affiliations. 